\title{
EFFICACY OF SOME PLANT EXTRACTS AND THE COMMERCIAL BIOCIDE, DOLPHIN ON POTATO TUBER WORM, Phthorimaea operculella (ZELLER.) (LEPIDOPTERA: GELECHIIDAE) UNDER FIELD AND STORAGE CONDITIONS Abou Hatab, Eftkhar E. ; Neveen F. Arafat and Naglaa F. Riad Plant Protection Research Institute, (ARC). Dokki, Giza.Egypt
}

\begin{abstract}
Field and laboratory experiments were conducted at Aga district ,Dakahlia Governorate during two successive seasons 2009 and 2010 to evaluate the efficiency of some plant extracts (demises ) and plant oils(mint oil- fennel oil -cumin oil) in comparison with the biocide (dolphin )against Phthorimaea operculella(Zeller.)

The obtained results showed that the mint oil was the most effective against $P$. operculella larvae $(74.2,75.9 \%)$, followed by fennel oil $(62.7,74.2 \%)$; cumin oil $(62.6$, $69.1 \%)$ and demises plant extracts $(61.5,60.5 \%)$. While, dolphin caused a relatively high mortality rate of PTM larvae( 82.6 \&81.4\%) during2009 \&2010 seasons.

The results indicated that the bioactivity of the tested materials were concentration-dependent, whereas, the inhibition rates of moths resulted from eggs or pupae or moths infestation increased obviously with the rise of concentration. Meanwhile, the bioactivity of all were relatively the most to moths infestation all tested materials than eggs and pupae.
\end{abstract}

\section{INTRODUCTION}

Potato (Solanum tuberosum L.) is an important vegetable crop in Egypt, which is seriously infested by the potato tuber moth, Phthorimaea operculella (Zell.) (Lepidoptera : Gelechiidae) especially, in the field and in stores (Abd El-Salam et al., 1972), Shaheen (1979), Heeder (1983), Doss (1984), Iskander (1985); Khalil et al. (1987) and Ahmed et al (1991). Infested tubers become completely unmarketable. Chemical control of potato tuber moth is a costly input that contaminated the environment, increase resistance to insecticides and can also cause health hazards for the humans. The present work aims to study the population fluctuation of potato tuber moth $P$. operculella with relation the level infestation with different plant growth stages. Also, field and laboratory studies were carried out evaluate demises plant extract and some plant oils against $P$. operculella larvae.

\section{MATERIALS AND METHODS}

Field and laboratory experiments were conducted in 2009 and 2010 growing seasons to determine the effects of selected plant extracts and the commercial biocide (Dolphin) on the potato tuber moth (PTM). These materials were subjected in Table (1). 
Abou Hatab, Eftkhar E. et al.

Field experiments :-

An area of about 1/4 feddan at Aga district, El-Dakahlia Governorate was selected and divided into 18 plots (each about $55 \mathrm{~m} 2$ ). The experimental replicates were arranged in complete randomized block design with three replicates for each treatment. The planting dates were on the 26 and 14 of January for 2009 and 2010 seasons. Sponta variety was cultivated as recommended whereas. All agricultural practices were followed.

To determine the effect of some plant extracts and the commercial biocide (Dolphin) on the potato tuber moth (PTM), P. operculella Zeller population, seasonal abundance of PTM larval population was estimated in treated and untreated potato fields throughout two successive years 2009 and 2010.

Inspection of plants was carried out before spray and after 10 days from application to investigate the effect of the different treatments on the reduction rates of PTM larvae populations.

-The efficacy of the previously mentioned plant extract and plant oils were investigated against PTM as follows:

The reducing percentage in infestation was corrected by using Abbott's formula (Abbott, 1925):-

$A-B$
Reduction in infestation $\%=\frac{-}{A}-{ }^{----~} X 100$

Where $A=$ number of infested tubers in control

$B=$ number of infested tubers in treatment

\section{Estimating the role of some plant extracts and the biocid (Dolphin) on PTM population:-}

Sampling were taken after twenty one days from sowing date. Intervals between each samples were 7 days. Each sample consisted of 10 leaflets picked at random. Collected samples were transferred to the laboratory in paper bags for investigations. The collected samples were examined weekly by using a binocular-microscope to determine the population fluctuation of $P$. operculella larvae in treated and untreated plots. The number of $P$. operculella larvae present in each sample was recorded.

\section{Laboratory experiments :-}

This laboratory experiment was carried out to compare the efficiency of the previously mentioned natural products against $P$. operculella eggs, larvae and adults.

75 infested potato tubers with PTM eggs approximately equal in size were collected and divided into three replicates (each replicate contain 25 tubers). After that ,potato tubers were treated using various concentrations (5, $2.5,1.25$ and $0.75 \% \mathrm{~W} / \mathrm{V}$ ) were prepared from the stock solution for the extract of Demises leaves, fennel oil ;mint oil and cumin oil for conducting the experiments. Three replicates were used for each concentration. Experiments were carried out at $25 \pm 2{ }^{\circ} \mathrm{C}$ and $70 \pm 5 \% \mathrm{R}$.H. Then the numbers of emerged moths were recorded for one week from the initial moth emergence. 
Table 1: The common and scientific names and rate of application of the tested compounds.

\begin{tabular}{|l|l|c|}
\hline Compound and scientific names & Family & Rate of application \\
\hline 1-Cumin oil (Cumminum cyminum L.): & Umbelliferae & $200 \mathrm{ml} / 100 \mathrm{~L}$ water \\
\hline 2- Mint oil (Mentha piperita L.) & . Labiatae & $200 \mathrm{ml} / 100 \mathrm{~L}$ water \\
\hline 3-fennel oil(Feoniculum vulgare L.) & Umbelliiferae & $200 \mathrm{ml} / 100 \mathrm{~L}$ water \\
\hline 4-Demises, Ambrosia maritime, & Compostiae) & $600 \mathrm{ml} / 100 \mathrm{~L}$ water \\
\hline 5-Dolphin 85 \%, WG, B.T & \multicolumn{2}{|c|}{$200 \mathrm{gm} /$ Fadden } \\
\hline $\begin{array}{l}\text { Cumin, mint and fennel oils were bought from the local market, while demises extract } \\
\text { was obtained from Horticulture Research Institute (HRI) Egypt, }\end{array}$ \\
\hline
\end{tabular}

\title{
Statistical analysis:
}

The mortality was corrected using Abbott's formula (1925) with data under the store.

"a Costat" a product of cohort soft ware was used to differentiation between means.

The reduction percentages (\% mortality) of different tested materials in the field were calculated according Hinderson and Tilton (1955).

The reduction percentages of the emerged moths from the pupae and eggs were calculated using the following equation:

No. of emerged moths in control - No. of emerged moths in treatment

\author{
Inhibition $=\longrightarrow$ X 100 \\ No. of emerged moths in control
}

\section{RESULTS AND DISCUSSION}

The data illustrated in Table (2) showed that infestation by Phthorimaea operculella started at 45 days after sowing on March $11^{\text {th }} 2009$ season,(4.8 larvae/10 leaves) on Sponta variety, then increased gradually to reach its maximum (13.9 larva/10 leaves) 108 days after sowing on April $23^{\text {rd }}$ , after that the population decreased gradually to reach (3.0 larvae/10 leaves) when plant age 122 days on May $28^{\text {th }}$. Meanwhile, data indicated that the larval stage increased as well as potato plants growth increased, whereas, the level of infestation with potato tuber moth $P$. operculella during the two seasons ,2009 and 2010. PTM larval population started in few numbers, then increased gradually till reached it peak when potato plants age of 108 and 114 days during the two seasons.

In the second season, the obtained results showed that infestation by $P$. operculella stated at 58 days after sowing on March $13^{\text {th }} 2010$ season: (4.5 larva/10 leaves) on Sponta variety, then increased gradually to reach its maximum (12.7 larva/10 leaves) 114 days after sowing on May $15^{\text {th }}$ on Sponta variety. 
Abou Hatab, Eftkhar E. et al.

Data show also that incidence of infestation by $P$. operculella as expressed by counts of larvae stage increases sharply with the increase of potato plants age to reach its maximum incidence at 114 days, and infestation dropped to reach minimum rates at ages of more than 128 days on the potato Sponta variety, (Table 2). The obtained data are in agreement with those of Mikhael (1995); Dawood et al. (1999); Stein and Vendramin (2000) and Gomma (2002).

Table (2): Mean larval numbers of the potato tuber moth $\boldsymbol{P}$. operculella in relation to plant age for potato at DaKahlia Governorate during summer plantation of 2009 and 2010 seasons.

\begin{tabular}{|c|c|c|c|c|c|}
\hline \multirow[t]{2}{*}{$\begin{array}{c}\text { Date of } \\
\text { inspection }\end{array}$} & \multirow[t]{2}{*}{$\begin{array}{c}\text { Plant age } \\
\text { (day) }\end{array}$} & $\begin{array}{c}\text { Mean } \\
\text { larval } \\
\text { numbers } \\
\text { /25 plant } \\
\text { leaves }\end{array}$ & \multirow[t]{2}{*}{$\begin{array}{c}\text { Date of } \\
\text { inspection }\end{array}$} & \multirow[t]{2}{*}{$\begin{array}{c}\text { Plant age } \\
\text { (day) }\end{array}$} & $\begin{array}{c}\text { Mean larval } \\
\text { numbers } / 25 \text { plant } \\
\text { leaves }\end{array}$ \\
\hline & & Sponta & & & Sponta \\
\hline $5 / 2 / 2009$ & 10 & 0.0 & $6 / 2 / 2010$ & 23 & 0.0 \\
\hline $12 / 2$ & 17 & 0.0 & $13 / 2$ & 30 & 0.0 \\
\hline $19 / 2$ & 24 & 0.0 & $20 / 2$ & 37 & 0.0 \\
\hline $26 / 2$ & 31 & 0.0 & $27 / 2$ & 44 & 0.0 \\
\hline $4 / 3$ & 38 & 0.0 & $6 / 3$ & 51 & 0.0 \\
\hline $11 / 3$ & 45 & 4.8 & $13 / 3$ & 58 & 4.5 \\
\hline $18 / 3$ & 52 & 5.7 & $20 / 3$ & 65 & 5.4 \\
\hline $25 / 3$ & 59 & 6.6 & $27 / 3$ & 72 & 5.3 \\
\hline $2 / 4$ & 66 & 6.6 & $3 / 4$ & 79 & 6.4 \\
\hline $9 / 4$ & 73 & 7.8 & $10 / 4$ & 86 & 8.6 \\
\hline $16 / 4$ & 80 & 8.9 & $17 / 4$ & 93 & 8.7 \\
\hline $23 / 4$ & 87 & 9.7 & $24 / 4$ & 100 & 9.4 \\
\hline $30 / 4$ & 94 & 9.5 & $1 / 5$ & 107 & 11.6 \\
\hline $7 / 5$ & 101 & 11.8 & $8 / 5$ & 114 & 12.7 \\
\hline $14 / 5$ & 108 & 13.9 & $15 / 5$ & 121 & 9.4 \\
\hline $21 / 5$ & 115 & 4.9 & $22 / 5$ & 128 & 2.3 \\
\hline $28 / 5$ & 122 & 3.0 & $29 / 5$ & 135 & 0.0 \\
\hline $4 / 6$ & 128 & 0.0 & $5 / 6$ & 142 & 0.0 \\
\hline \begin{tabular}{|l|} 
Mean \pm S.E.of \\
actual \\
values
\end{tabular} & & $5.2 \pm 0.73$ & $\begin{array}{l}\text { Mean } \pm \text { S.E. of } \\
\text { actual values }\end{array}$ & & $4.7 \pm 0.86$ \\
\hline
\end{tabular}

The results in Table (3) the mortality in case of after first spray and second spray on treated with Cumin oil, fennel oil, Mint oil, Demises plant extract and Dolphin were (55\%\& 70.9); (63.5\&79.4) ;(63.5\&89.4); (50\&73.1\% ) and $(85 \& 80.2 \%)$, with fife compounds, respectively, during 2009 season..

The mortality the second season showed nearly the same trend as indicated with after first and second spray. However, all compounds caused a significant mortality in general mean of larvae as compared with control. Also, the Dolphin was relatively the most efficient compound in protecting potato tubers against $P$. operculella

These results agree with the findings Raman et al(1987); Lal (1987) and Doss et al. (1994) stated that L. camara significant reduced Sponta damage when compared with the untreated control and with those covered with rice straw. 
Table (3):Efficiency of certain treatments against Phthorimaea operculella (Zeller) larvae on potato plants during two seasons at Dakahlia Governorate.

\begin{tabular}{|c|c|c|c|c|c|c|c|c|c|c|c|c|c|}
\hline \multirow{5}{*}{ 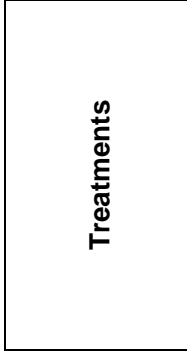 } & \multirow{5}{*}{ 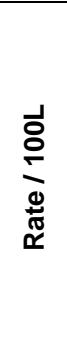 } & \multirow{5}{*}{$\begin{array}{l}\text { 히 } \\
\text { 음 } \\
d \\
\text { 이 }\end{array}$} & \multicolumn{11}{|c|}{ Mean larval number } \\
\hline & & & \multicolumn{11}{|c|}{ Application } \\
\hline & & & \multicolumn{5}{|c|}{2009} & \multicolumn{6}{|c|}{2010} \\
\hline & & & \multicolumn{2}{|c|}{ 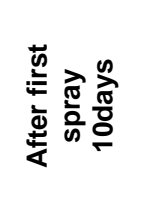 } & \multicolumn{2}{|c|}{ 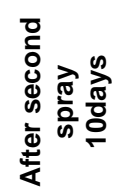 } & \multirow{2}{*}{ 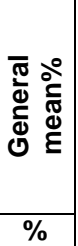 } & \multirow[t]{2}{*}{ 힌 } & \multicolumn{2}{|c|}{ 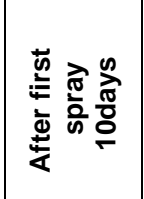 } & \multicolumn{2}{|c|}{ 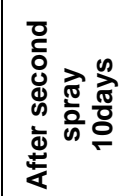 } & \multirow{2}{*}{ 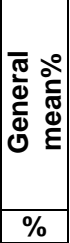 } \\
\hline & & & No. & $\%$ & No. & $\%$ & & & No. & $\%$ & No. & $\%$ & \\
\hline Cumin oil. & 200 & 25 & 15 & 55 & 11 & 70.9 & 62.6 & 13 & 7 & 66.1 & 7 & 72.0 & 69.1 \\
\hline fennel oil & 200 & 32 & 17 & 63.5 & 10 & 79.4 & 62.7 & 18 & 9 & 68.5 & 7 & 79.9 & 74.2 \\
\hline Mint oil. & 200 & 35 & 17 & 63.5 & 8 & 89.4 & 74.2 & 21 & 9 & 64.0 & 5 & 87.7 & 75.9 \\
\hline $\begin{array}{l}\text { Demises plant } \\
\text { extract }\end{array}$ & 600 & 27 & 18 & 50 & 11 & 73.1 & 61.5 & 14 & 11 & 50.5 & 8 & 70.4 & 60.5 \\
\hline Dolphin & 50 & 20 & 4 & 85.0 & 6 & 80.2 & 82.6 & 9 & 2 & 80.1 & 3 & 82.7 & 81.4 \\
\hline Control & -- & 33 & 44 & --- & 50 & --- & - & 29 & 46 & - & 56 & --- & - \\
\hline
\end{tabular}

The effectiveness of plant extract; cumin oil; fennel oil and mint oil against $P$. operculella is demonstrated in Tables $(4,5,6$, and 7$)$.

The results of cumin oil given in Table (4) showed that the average numbers of emerged adults from egg, pupa and moth treatments were reduced with the increase of concentration.

The recorded numbers were, 30.6, 22.6, 16.5 and 10.9 emerged adults from eggs treatments, 29.5, 27.2, 24.0 and 15.5 emerged adults from pupae treatments and 30.5, 29.0, 25.0 and 12.0 emerged adults from moth treatments at the previously mentioned concentrations, respectively.

The obtained results revealed that the efficacy of agent dependent on concentration. The highest mortalities of the treatments were observed at the highest tested concentration.

In this respect, El-wahab et al., (2003) indicated that mortalities of cumin oil of were some what higher at the highest concentration of $10 \%$, to some stored product insects.

Response of $P$. operculella to mint oil is given in Table (4). The results indicated that inhibition rates of moths resulted from eggs, pupae and moth treated dependent on concentration. The highest inhibition rates of moths emerged were $60.3,69.9 \%$ and $71.4 \%$ of eggs, pupae and moths treated with the highest concentration ( $5 \% \mathrm{~W} / \mathrm{V})$ of mint oil for eggs, pupae and moths, respectively, while the lowest reduction rates of moth emergence $(12.9,10.0$ and $35.7 \%)$ were recorded at the lowest concentration $(0.75 \% \mathrm{~W} / \mathrm{V})$.

A result of the response of $P$. operculella of fennel oil was given in Table (5). The number of emerged moths was gradually reduced with increasing the concentration at all treatments when compared with control. Consequently, the inhibition rates of moth emergence increased as 
increasing the concentration at all treatments, reaching between $12.2-58.8 \%$, 10.5-56.0 \% and 8.5-68.9 \% in egg, pupa and moth treatments for fennel oil.

Response of $P$. operculella to demise plant extract is given in Table (6). The results indicated that inhibition rates of moths resulted from eggs; pupae and moths treatment concentrations. The highest inhibition rates of moth's emergence were $55.0,51.0$ and $64.1 \%$ of eggs, pupae and moth treatments at the highest Concentration (5\%), respectively. While, the lowest reduction rates of moth emergence $(8.0,7.1$ and $18.8 \%)$ were recorded at the lowest concentration $(0.75 \%)$. The obtained results are in complete harmony with that obtained by Kroschel and Koch (1996)when they Studied that the toxicity of three plant extracts, namely chinaberry (Melia azedarch), neem (Azadirachta indica)) on the reduction of $P$. operculella.

Results indicate that the tested plant extract and plan oils were slightly more effective in moths and pupae treatments than eggs treatment and showed promising results at the highest concentrations of the different tested materials. Thus, these plant oils and leaves extracts could be used as tuber Protestants against this species frame of an integrated pest management program (IPM).

Also, the obtained results coincided with the findings of other investigators (Reddy and Urs., 1989; Salem, 1991, Sabbour and Ismail, 2002) and Mikhael,(1995).

Table (4): Response of Phthorimaea operculella (Zeller) to cumin oil (Cuminum cyminum).

\begin{tabular}{|c|c|c|c|c|c|c|}
\hline 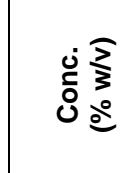 & 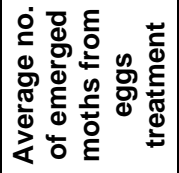 & 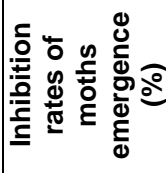 & 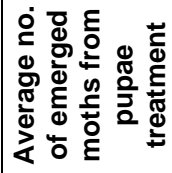 & 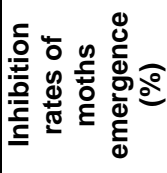 & 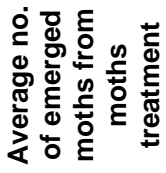 & 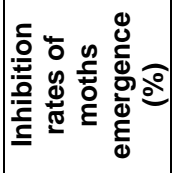 \\
\hline 5 & $10.9 \pm 3.1$ & 68.8 & $15.5 \pm 2.2$ & 58.0 & $12.0 \pm 2.8$ & 70.0 \\
\hline 2.5 & $16.5 \pm 2.9$ & 52.8 & $24.0 \pm 3.4$ & 35.1 & $25.0 \pm 3.6$ & 37.5 \\
\hline 1.2. & $22.6 \pm 2.6$ & 35.4 & $27.2 \pm 2.5$ & 26.4 & $29.9 \pm 3.1$ & 27.5 \\
\hline 0.75 & $30.6 \pm 3.2$ & 12.6 & $29.5 \pm 2.9$ & 20.2 & $30.5 \pm 2.4$ & 23.8 \\
\hline Control & 35.0 & - & 37.0 & - & 40.0 & - \\
\hline
\end{tabular}

Table (5): Response of Phthorimaea operculella (Zeller) to mint oil (Mentha piperita L).

\begin{tabular}{|c|c|c|c|c|c|c|}
\hline $\begin{array}{ll}0 \\
0 \\
0 \\
0 \\
0\end{array}$ & 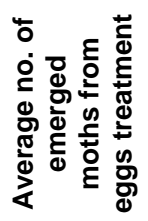 & 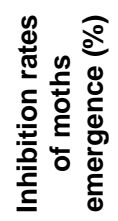 & 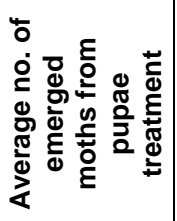 & 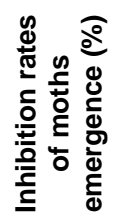 & 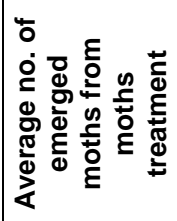 & 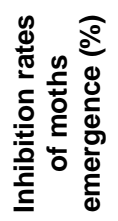 \\
\hline \begin{tabular}{|l|}
5 \\
2.5 \\
1.2 .5 \\
0.75 \\
Control \\
\end{tabular} & $\begin{array}{c}11.9 \pm 2.6 \\
13.2 \pm 3.4 \\
16.4 \pm 3.2 \\
20.8 \pm 1.9 \\
30\end{array}$ & $\begin{array}{l}60.3 \\
56.0 \\
45.3 \\
30.6\end{array}$ & $\begin{array}{c}10.0 \pm 2.1 \\
17.8 \pm 2.5 \\
19.5 \pm 2.3 \\
23.5 \pm 2.7 \\
33 \\
\end{array}$ & $\begin{array}{l}69.9 \\
46.0 \\
40.9 \\
28.7\end{array}$ & $\begin{array}{c}10.0 \pm 2.3 \\
14.0 \pm 1.9 \\
19.0 \pm 1.8 \\
22.5 \pm 2.7 \\
35 \\
\end{array}$ & $\begin{array}{l}71.4 \\
62.8 \\
45.7 \\
35.7\end{array}$ \\
\hline
\end{tabular}


Table (6): Response of Phthorimaea operculella (Zeller) to fennel oil (Feoniculum vulgare $\mathrm{L}$ ).

\begin{tabular}{|c|c|c|c|c|c|c|}
\hline 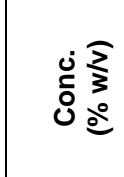 & 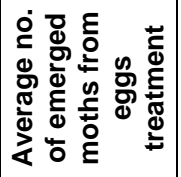 & 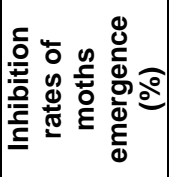 & 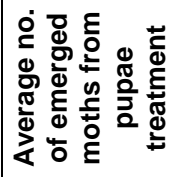 & 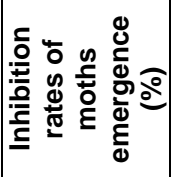 & 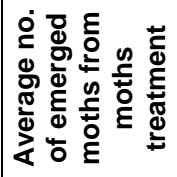 & 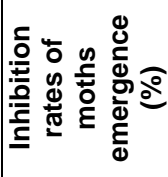 \\
\hline \begin{tabular}{|l|}
5 \\
2.5 \\
1.2 .5 \\
0.75 \\
Control \\
\end{tabular} & $\begin{array}{c}18.5 \pm 3.1 \\
26.5 \pm 2.9 \\
32.5 \pm 2.6 \\
39.5 \pm 3.2 \\
45 \\
\end{array}$ & $\begin{array}{c}58.8 \\
41.1 \\
32.2 \\
12.2 \\
- \\
\end{array}$ & $\begin{array}{c}20.5 \pm 2.2 \\
28.5 \pm 3.4 \\
33.5 \pm 2.5 \\
42.5 \pm 2.9 \\
47.5 \\
\end{array}$ & $\begin{array}{c}56.8 \\
40.0 \\
29.4 \\
10.5 \\
- \\
\end{array}$ & $\begin{array}{c}13.5 \pm 2.8 \\
26.5 \pm 3.6 \\
33.5 \pm 3.1 \\
40.0 \pm 2.4 \\
43.5 \\
\end{array}$ & $\begin{array}{c}68.9 \\
39.1 \\
22.9 \\
8.5 \\
- \\
\end{array}$ \\
\hline
\end{tabular}

Table (7):Response of Phthorimaea operculella (Zeller) to demises plant extract (Ambrosia maritime).

\begin{tabular}{|c|c|c|c|c|c|c|}
\hline 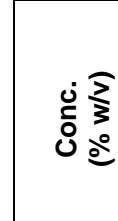 & 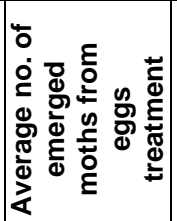 & 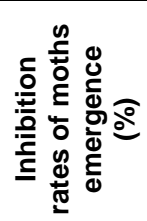 & 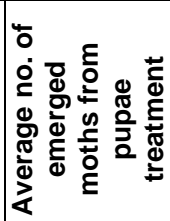 & 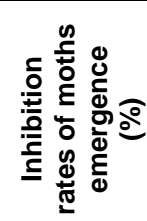 & 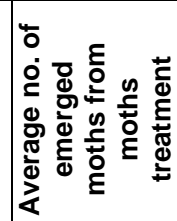 & 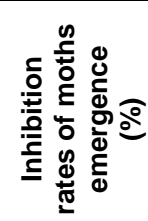 \\
\hline & $22.5 \pm 3.1$ & 55.0 & $24.0 \pm 2.2$ & 51.0 & $19.0 \pm 2.8$ & 64.1 \\
\hline 2.5 & $27.0 \pm 2.9$ & 46.0 & $32.6 \pm 3.4$ & 33.4 & $26.9 \pm 3.6$ & 49.2 \\
\hline 1.2 .5 & $43.5 \pm 2.6$ & 13.0 & $36.0 \pm 2.5$ & 26.5 & $36.5 \pm 3.1$ & 33.3 \\
\hline 0.75 & $46.0 \pm 3.2$ & 8.0 & $45.5 \pm 2.9$ & 7.1 & $43.0 \pm 2.4$ & 18.8 \\
\hline & 50.0 & & 49.0 & & 53.0 & \\
\hline
\end{tabular}

\section{REFERENCES}

Abbott, W. S. (1925): A method of computing the effectiveness of insecticides. J. Econ. Entomol., 18: 265-207.

AbdEI-Salam, A. M.; Assem, M. A.; Hamad, S. M. and Eid, G. H. (1972): Studies on potato pest in UAR II. Susceptibility of some potato insects' infestation in the field .Z. Angew. Ent. 70 (1): 76-82. (c.f. A.R.E., 62 : 1526).

Abd El-Wahab, H. A.; El-Adl, F. E.; Soad, A. Ibrahim and El-Bouze, M. F. R. (2003): Efficiency of certain materials against potato tuber moth, Phthorimaea operculella (Zeller) and its parasitoids with special regard to their residues. $2^{\text {nd }}$ International Conference, Plant Prot. 735-741.

Ahmed, S. A.; Ali, A. M. and Salman, A. M. (1991): Influence of potato varieties, nitrogen fertilization and plant growth regulators on the infestation level of Myzus persicae in potato fields. Triennial Conf. of European Assoc. For potato Res. (EAPR), Edinburgh (U.K.), 8-13 July, 56-57. 
Dawood, M. Z.; El-Rafie, K. K. and Haydar, M. F. (1999): Susceptibility of some potato cultivars to the potato tuber moth, Phthorimaea operculella (Zeller) infestation with relation to yield at Giza Governorate. J. Appl. Sci., Egypt, 14 (4).

Doss, S. A. (1984): Relative susceptibility of seventeen potato varieties to infestation by three insect pest's infestation in stores. Bull. Soc. Ent. Egypt, 65: 157-167.

Gomaa, A. S. A. (2002): New approaches to control the potato tuber moth, Phthorimaea operculella (Zeller) on potato in the A.R of Egypt. Ph. D. thesis, Sci. Tanta Univ., 1-164.

Heeder, M. F. (1983): Ecological and pest management studies on the potato tuber moth, Phthorimaea operculella (Zeller). Ph. D. Thesis, Fac. Agric., Ain Shams Univ.

Hinderson, C. F. and Tilton, E. W. (1955): Test with acaricides against the brown white mite. J. Econo. Entomo., 48: 157-161.

Iskander, N. N. (1985): Ecological and biological studies on Phthorimaea operculella (Zeller). M. Sc. Thesis, Fac. Agric. Zagazig Univ., Egypt

Khalil, F. M.; Abdel-Galil, F. A.; Ali. A. M. and Soliman, M. M. (1987): Susceptibility of certain potato varieties to Assuit. J. Agric. Sci., 18 (3): 215-233.

Kroschel,J. and koch,W.(1996):Studies on the use of chemicals the potato tuber moth in potato stores. Crop protection, 15-2,197-203.

Lal, L. (1987): Studies on natural repellents against potato tuber moth, Phthorimaea operculella (Zeller) in country stores. Potato Res., 30 (2): 329-334 .

Mikhael, R. H. (1995): Studies on insect pests infesting potato crop and their control by using non-chemical methods. Ph.D. Thesis, Plant Protection Department Fac. Agric. Moshtohor Benha Branch, Zagazig Univ.

Raman, K. V.; Both, R. H. and Palacois, M. L. (1987): Control of potato tuber moth, Phthorimaea operculella (Zeller) in rustic potato stores. Trop. Sci., 27: 175-194.

Reddy, G. V. P. and Urs, K. C. D. (1989): Effects of tribulus terrestris Linn. On the development of potato tuber moth, Phthorimaea operculella (Zeller) (Lepidoptera: Gelechiidae). Current Science, 58 (4): 212-213.

Sabbour, M. and Ismail, I. A. (2002): The combined effect of microbial control agents and plant extracts against potato tuber moth, Phthorimaea operculella (Zeller). Bulletin of National Research Center, Cairo, 2002, 27: 4, 459-467.

Salem, S. A. (1991): Evaluation of neem seed oil as tuber protecting against Phthorimaea operculella (Zeller) (Lepidoptera: Gelechiidae). Annals of Agricultural Science Moshtohor, 29:1, 589-595.

Shaheen, A. H. (1979): Some ecological and biological studies on the potato tuber moth, Phthorimaea operculella in Egypt. Bull. Ent. Soc., Egypt, 65: 345-350.

Stein, C. P. and Vendramin, J. D. (2000): Antibiosis of potato clones to Phthorimaea operculella (Zeller) (Lepidoptera: Gelechiidae). Anais da Sociedade Entomologic do Brasil, 29: 4, 783-788. 


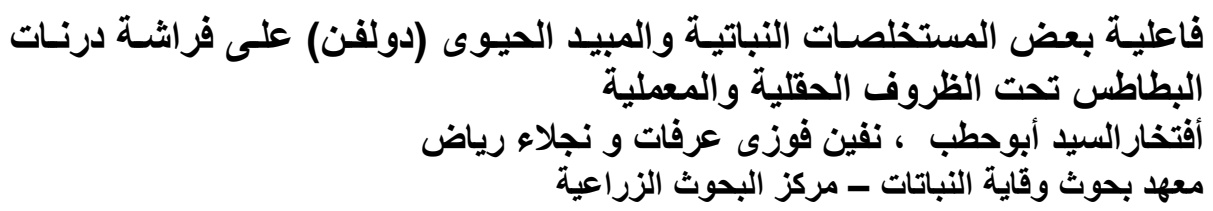

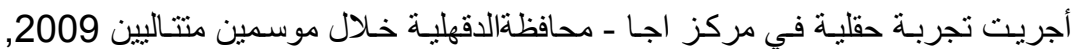

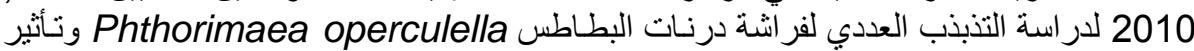

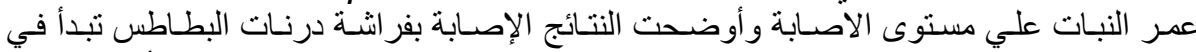

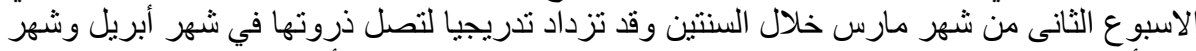

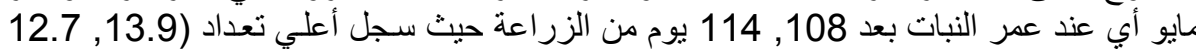

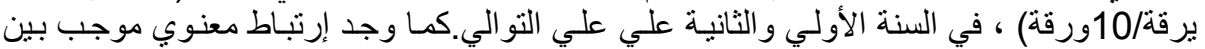

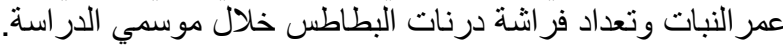

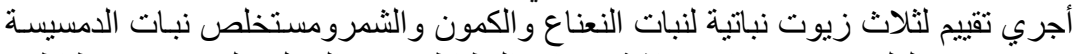

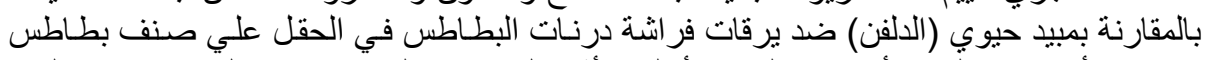

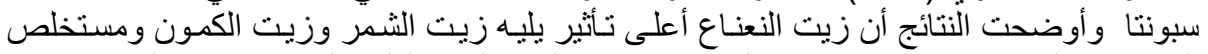

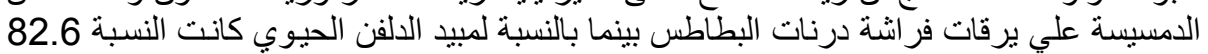
و81.4\% على التو الى خلال السنتين.

كلية الزراعة - جامعة المنصورة مركز البحوث الزراعية

$$
\begin{aligned}
& \text { قام بتحكيم البحث } \\
& \text { أ.د / عبد الستار ابراهيم عبد الكريم } \\
& \text { أ.د / حسن على طه أد الدئ }
\end{aligned}
$$

